\title{
Notices of Remains of Ecclesiastical Architecture in Norfolk, Supposed to be of the Saxon Period
}

\section{The Rev. John Gunn M. A.}

To cite this article: The Rev. John Gunn M. A. (1849) Notices of Remains of Ecclesiastical Architecture in Norfolk, Supposed to be of the Saxon Period, Archaeological Journal, 6:1, 359-363, DOI: $10.1080 / 00665983.1849 .10850740$

To link to this article: http://dx.doi.org/10.1080/00665983.1849.10850740

册 Published online: 10 Jul 2014.

Submit your article to this journal $[\pi$

Q View related articles $\asymp$ 


\section{NOTICES OF REMAINS OF ECCLESIASTICAL ARCHITECTURE IN NORFOLK, SUPPOSED TO BE OF THE SAXON PERIOD.}

BY THE REV. JOHN GUNN, M. A., RECTOR OF IRSTEAD.

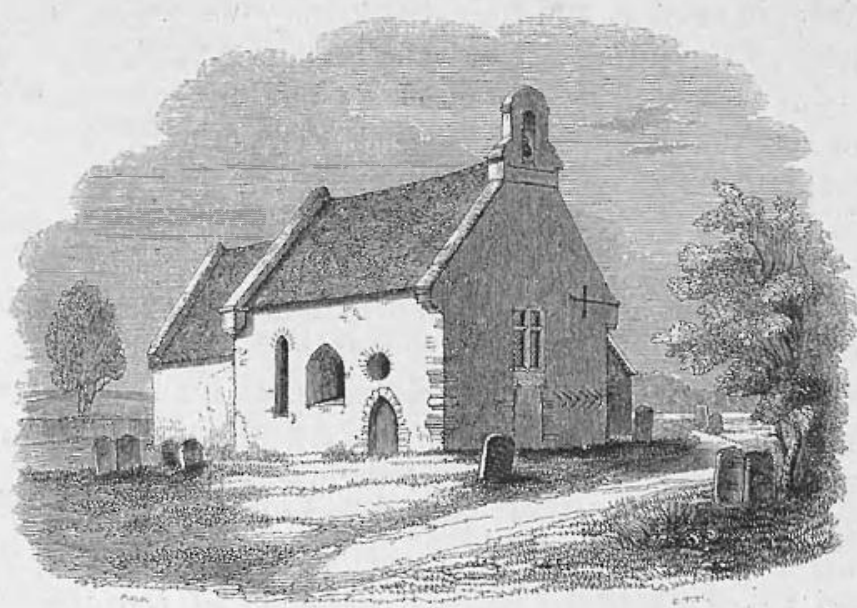

St. Andrew's, Framlingham Pigot.

When the Archaeological Institute held its Meeting at Norwich, I availed myself of that opportunity to submit to the Society an account of some ancient remains in the tower and north wall of the church of Beeston St. Lawrence, in Norfolk. My object was to obtain information respecting their date, a point on which I was unable to satisfy myself. They were, apparently, of Saxon character, but still such as are occasionally found in later buildings. Besides, it appeared to me most probable that the peculiarities of Saxon architecture were not laid aside at once at the Conquest, and that in districts exposed to hostile incursions, churches continued to be built on the Saxon type as before, with narrow windows placed high in the walls, and adapted for the purposes of security and defence.

These considerations inclined me to doubt the antiquity of such remains; but I have since observed several similar remnants of ancient churches, which convince me that Saxon 
work, especially in remote villages, is more common than is generally supposed.

The first of these to which I beg to call attention, is part of the north and west walls of the.church of St. Margaret, at Witton, near North Walsham.

But, before entering upon a description of it, I will mention that in this and other parishes to which I shall have occasion to refer, it is recorded in Domesday that Saxon churches were in existence at the time the survey was made, and the shortness of the interval between the survey and the enlargement of these churches, which took place in the early English period, renders it improbable that there should have been intermediate structures.

It is possible, however, that the Saxon churches in question were constructed of wood, and might have been pulled down and replaced by more substantial fabrics in the Norman era, and afterwards altered and enlarged in the early English.

The peculiar features, therefore, of the buildings themselves, with respect to form and material, must be regarded as the only legitimate criteria of their date.

The accompanying representation of St. Margaret's Church, Witton, shows a quoining of rough native carr-stone, which marks the extent of the original nave, about two-thirds the length of the present, or 39 feet. The quoinings of the south angle of the ancient west wall which remains, point out also the width of the nave, viz., 13 feet. The height of the original wall is shown by the tier of perpendicular clerestory windows which has been added above, together with a large flat-headed window below. Above the north door (which is early English, and a subsequent insertion) are two small, round, double-splayed windows. This form of windows, I believe, may be regarded as the most dependable, if not infallible, characteristic of Saxon work. The continuation of the north wall of the nave and the chancel are also of the early English period, as the piscina, and priests' seats with the tooth-moulding prove. And it should also be remarked, that, whereas the round windows are of rubble and flint, the jambs and arches of the more recent doors and windows are of ashlar freestone. The round tower has been rebuilt, and the ancient south wall of the nave taken down to make room for an aisle.

In the church of St. Andrew, Framlingham Pigot (of which 


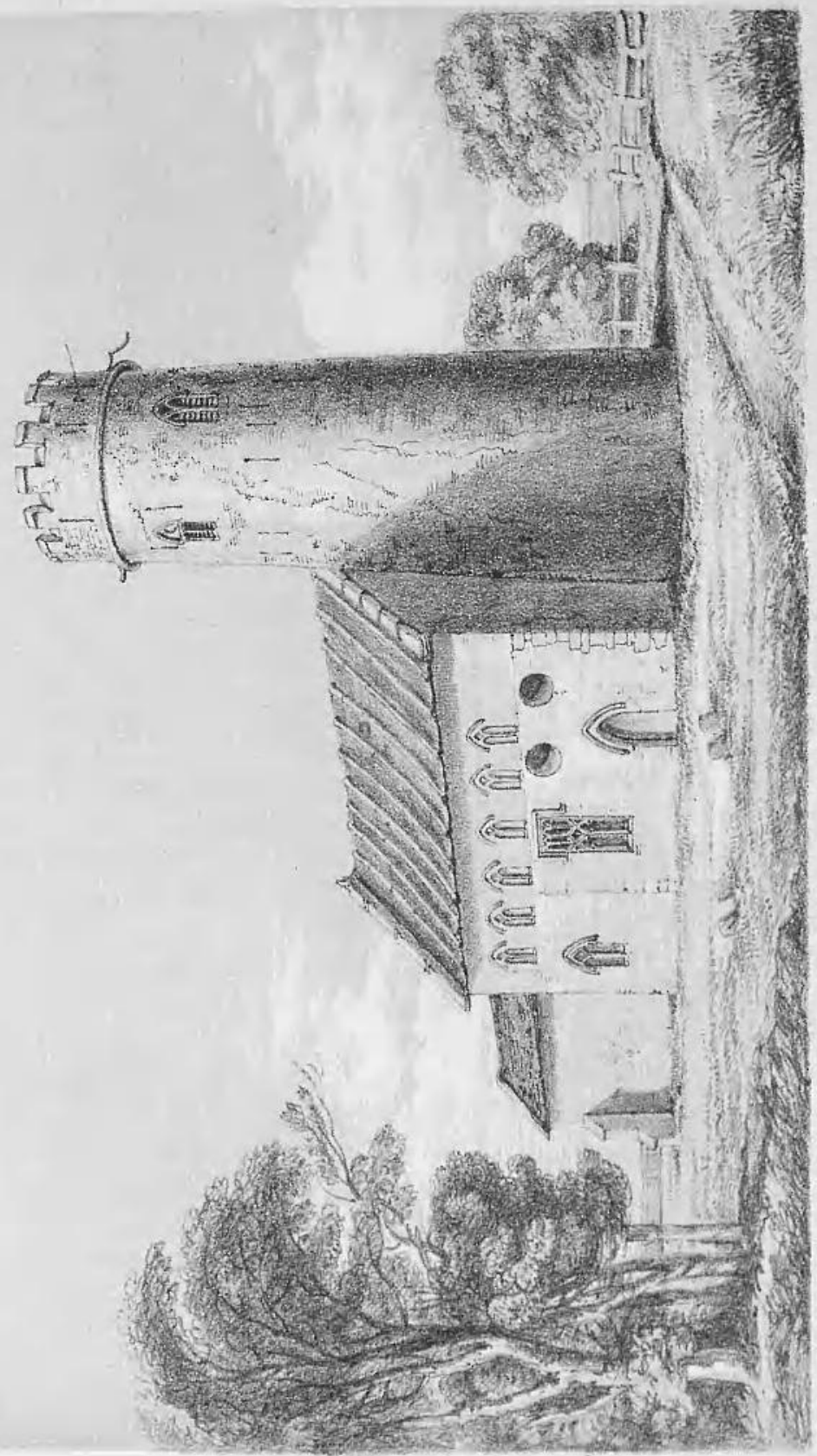


a sketch is given), similar double splayed windows, both circular and oblong, occur in the nave and in the chancel. The

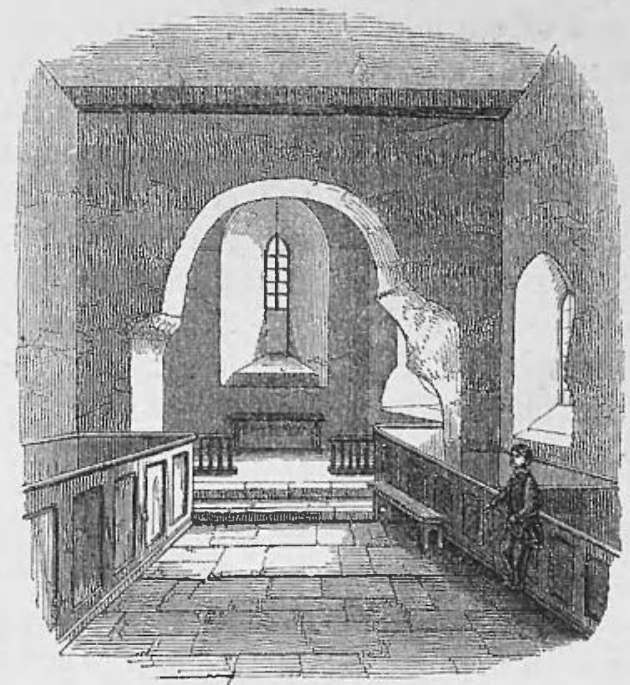

Chancel Arch, Framlingham Pigot.

entire church is of one period, except the more modern windows and doors, which have been inserted. Some early English windows are put into the places of the original double splayed ones, and a small piscina and priest's seat occupy the opening of one of them. In the original church there do not appear to have been any piscina or sedilia. All the quoinings of the church are of Roman shaped tiles, and, in some places, herring-bone work is seen. The old windows are of rubble, but the jambs and arches of the more recent windows and doors are of ashlar freestone. The height of the ancient gable of the nave may still be traced at a lower pitch than the present, the reverse of what is usually the case. There is no tower remaining. In the interior, the chancel arch itself is formed of rubble and flints, and the abacus and jambs have either been removed, so as to assume a trefoil-headed shape, or else the arch was originally left in that unfinished state, to be completed at some future time.

I mention this, as it throws light upon the corresponding chancel arch in the church of St. Andrew, Framlingham Earl, the adjoining parish. This church resembles the former, except that the quoinings are of rough flints. There is only

voL. vi. 
one double splayed round window remaining (at least that is visible), and, instead of the unsightly chancel arch in the sister church, there is a late Norman one of a very elaborate description and of exquisite beauty. The graceful arrangement of the mouldings is much to be admired. There are also two highly ornamented doorways on the north and south sides of the nave, which are etched by Cotman. These are of freestone, and the contrast of that material with the rubble work of the other portions of the church, affords a strong proof of the greater antiquity of the latter.

In the tower of the church of St. Julian, Norwich, there are also double splayed windows, and a trefoil headed window below, but the plastered walls of the nave and chancel will not allow further observations to be made.

In the church of St. Andrew, Colney, the tower likewise has double splayed arches. The tower arch leading into the nave is of a very rude and primitive construction, formed of thin flints of the shape best adapted to make an arch; and the abacus, of several pieces of rough stone, is also remarkable.

Similar double splayed windows occur in that gem of early churches, St. Mary, Great Dunham. This edifice has been so fully and frequently described, that I will only remark, with reference to the subject of this paper, that the long and short work of the quoins is of ashlar stone, and well and closely jointed. The enrichments of the straight-sided arch on the west side of the arcade, within the nave, and of the tower arches, and especially the hood-mouldings around them, together with the general plan of the church, similar to that of many Norman churches, all appear to me to indicate late Saxon work. At the same time, it is evident that the enrichments do not accord with the plainness of early Norman work.

The position of the small circular windows in the upper part of the tower has been pointed out to me as unique ; but the ruined tower of All Saints Church, Waborne, shows them in a similar place, on either side of a double straight-sided arch. The set-off beneath the circular arcade is composed of small flints, indicative of a great lack of free-stone, and 
incompatible with the abundance imported after the Norman conquest.

The only other church in which I have met with double splayed windows is that of All Saints, Melton Magna, which has quoinings of Roman shaped tiles, similar to those at Framlingham Pigot. ${ }^{3}$ I might mention besides, many other churches in which fragments of older buildings are retained, as at Tasburgh, North Walsham, Antingham, Swainsthorpe, East and. West Lexham, and other parishes. These will prove the justice of the observation of some old writer, whose name I do not remember, that our forefathers never rebuilt a church without preserving a portion of its predecessor.

USE OF BRONZE CELTS IN MILITARY OPERATIONS.

BY JAMES YATES, M.A., F.R.S.

Rend July 20th, 1849, at Salisbury.

THE design of the following remarks is to prove, that, among the various uses of bronze celts, one of the most important was the application of them in destroying fortifications and entrenchments, in making roads and earth-works, and in similar military operations. It will be observed, that I confine the inquiry to those celts which were made of bronze, and also to such as were adapted to be fitted to a straight wooden handle, and which belong to the fourth and fifth classes in Mr. Du Noyer's arrangement. ${ }^{1}$

I.-I shall first produce the passages of ancient Roman authors, which mention the application of dolabrce in the manner specified.

When Alexander the Great committed the rash act of leaping from the top of the wall into a city, which he was besieging, so as to put his life into extreme danger, some of his brave followers, "regardless of all peril, broke through

3 The church of St. John the Baptist, Cottishall, may be added, in which an ancient north wall remains with similar quoinings and herring-bone work of Roman-shaped bricks; and there are traces of a circular-headed door and two round windows above it, at present closed. Here also was $a$ church before the con- quest, and sepulchral urns, supposed to be Roman, are occasionally found. The use of such bricks in ecclesiastical buildings is not uncommon in localities which have been occupied by the Romans.

1 See Ârchaeological Journal, vol. iv,, pp. 2, 327.

On the subject of this memoir, I beg to 